\title{
Pariwisata Sebagai Sektor Unggulan Provinsi Sumatera Barat (Pendekatan Analisis Location Quotient)
}

\author{
Yenni Del Rosa \\ Universitas Dharma Andalas Padang \\ Correspondence email: rosa.yennidel@yahoo.com
}

\begin{abstract}
This study aims to determine the leading business fields that support the tourism sector in the South Coastal district and the province of West Sumatra. PDRB panel data were collected from the Central Statistics Agency in 2014 - $20 i 8$ with saturated sampling technique. To determine the leading business field per region, the Location Quetiont (LQ) method is used. The results of the LQ method analysis show that the South Coastal District has 4 leading business fields but the dominant one supporting the development of the tourism sector is only the agricultural business field ( $Q=1.70)$. Likewise, the province of West Sumatra has 7 leading business fields but the dominant one supporting the development of the tourism sector is only the transportation and warehousing business field $(L Q=2.54)$.
\end{abstract}

Keywords: tourism; leading sector and Location Quotient

\section{PENDAHULUAN}

Pariwisata salah satu sektor terbesar dan tercepat dalam kontributor perekonomian dunia. Tahun 2016 sektor ini berkontribusi sebesar 10\% dari total Gross Domestic Product (GDP) dunia dengan 1,235 juta wisatawan mancanegara, memperluas kesempatan kerja perbandingan $1: 10$ dan rangking 3 ekspor dunia setelah minyak bumi, bahan kimia dan produk otomotif serta makanan (Lenggogeni dan Elfindri, 2017). Hal ini sejalan dengan hasil penelitian (Arianti, 2014) bahwa multiflier effect semua sektor yang terkait dengan pariwisata berpengaruh relatif besar terhadap pengganda output, pendapatan rumah tangga dan tenaga kerja. Pariwisata tumbuh dan dinamis diikuti munculnya berbagai fragmentasi produk pariwisata di berbagai negara sehingga konsep pariwisata pun berkembang seperti pariwisata halal, co-creation digital tourism dan sustainable tourism, safety tourism dan lainnya. Semua perkembangan konsep ini muncul akibat rentannya industri pariwisata itu sendiri terhadap faktor-faktor eksternal global yang tidak dapat dihindari seperti meningkatnya trend jumlah wisatawan muslim dunia, meningkatnya intensitas krisis dan bencana, pengaruh era digital dan sharing economics sehingga berpengaruh pada keberlanjutan pariwisata yang berdampak pada trend wisata dunia.

Secara nasional munculnya fenomena baru pariwisata selayaknya direspon dengan berbagai metode dan strategi perencanaan, regulasi, model pemasaran dan pola pengelolaan pariwisata secara kontekstual yang diadopsi berbeda dari berbagai negara. Di Indonesia sendiri perkembangan pariwisata sebagai sektor unggulan pada program Nawacita pada Rencana Pembangunan Jangka Menengah (RPJMN) 2016 - 2020 yang berdampak pada euphoria dan meningkatnya kesadaran peranan pariwisata di berbagai daerah. Diikuti dengan peningkatan daya saing pariwisata Indonesia secara global meningkat dari posisi 70 dari 141 negara ke posisi 42 dari 136 negara tahun 2015 - 2017 melalui Travel and Tourism Competitiveness Index. Perkembangan pariwisata tidak hanya mengejar target secara kuantitatif dari perspektif demand dan dari perspektif supply tapi juga harus mampu mengimbangi fenomena global yang tidak bisa dihindari terutama dalam mendukung sustainable tourism development.

Pada tatanan pariwisata di level provinsi masih banyak muncul permasalahan dasar. Dibalik meningkatnya peranan community participatory di berbagai daerah dari seluruh stakeholders pariwisata, penyusunan perencanaan destinasi dan pengelolaan yang berbasis ultimate experience, desain pasar dan strategi pemasaran yang mesti menyesuaikan pada destinasi utama serta trend yang berlaku, pola pemberdayaan masyarakat pariwisata yang diukur melalui target parameter pariwisata masing-masing daerah ditinjau dari perspektif demand dan supply. Pariwisata melalui multiplier effect dapat mempercepat pertumbuhan ekonomi dan penciptaan lapangan kerja sehingga pemerintah menjadikan sektor pariwisata sebagai kekuatan dan daya saing bagi daerah-daerah lain di Indonesia (Erry, 2014) serta pariwisata dapat menciptakan ekonomi kreatif sebagai kategori potensial yang patut dkembangkan (Nurul, 2019). Langkah awal antisipasi dan akomodasi terhadap perubahan paradigma pembangunan di era reformasi, pemerintah 
telah mensyahkan dan memberlakukan UU No.22 tahun 1999 tentang Pemerintahan Daerah dan UU No.25 tahun 1999 tentang Perimbangan Keuangan Pusat dan Daerah yang memberikan implikasi tentang kewenangan Pemerintah Daerah sebagai pemeran utama pembangunan dalam hal perencanaan, pelaksanaan, evaluasi dan pembiayaan pembangunan (Mahmudi, 2010). Pemberlakuan kedua Undang-Undang tersebut selain berimplikasi positif bagi Pemerintah Daerah juga merupakan tantangan sehingga jika tidak diantisipasi dengan baik akan berdampak negatif.

Akselerasi sektor pariwisata tahun 2012 - 2017 berada di angka 1,22 dengan laju pertumbuhan di atas rata-rata pertumbuhan ekonomi nasional dibandingkan sektor lainnya (Adam, 2018). Keberadaan infrastruktur pariwisata yang memadai menjadi syarat peningkatan laju pertumbuhan sektor pariwisata. Pengembangan sarana transportasi, informasi dan penginapan sangat dibutuhkan dalam menarik minat wisatawan mancanegara butuh biaya $\mathrm{Rp} 4.000$ triliun. Jumlah tersebut dapat menghasilkan nilai tambah $\mathrm{Rp}$ 7.718 triliun atau 1,93 kali lipat. Dampak aktivitas ekonomi yang didukung oleh infrastruktur tersebut memberikan nilai tambah Rp 7.718 triliun dari nilai investasi infrastruktur dengan kontribusi tenaga kerja mencapai Rp 11,097 triliun (BPS, 2019).

Pemerintah perlu memberikan insentif yang lebih baik kepada pengelolaan Kawasan Ekonomi Khusus (KEK) sebab objek wisata sangat banyak mulai dari alam, jejak peradaban sampai yang kekinian. Namun kontribusi sektor pariwisata belum membanggakan karena salah satunya infrastruktur yang tidak memadai dan pengelolaannya lemah. Desain pembangunan pariwisata yang berdaya saing secara komprehensif harus mencakup pilar infrastruktur fisik, sumber daya manusia, keuangan dan pembiayaan serta tata kelola. Dimensi tersebut diharapkan bisa menjadi patokan terwujudnya sektor pariwisata yang berkualitas sebagai sumber pendapatan alternatif dan identitas bangsa di tingkat global. Kabupaten Pesisir Selatan memiliki cukup banyak destinasi wisata yang menjadi tujuan wisata di provinsi Sumatera Barat seperti Pantai Carocok Painan dengan pulau Cingkuak di kecamatan IV Jurai dan kawasan wisata Mandeh di kecamatan Koto XI Tarusan. Juga terdapat Bukik Langkisau, Air Terjun Bayang Sani, Air Terjun Timbulun, Jembatan Akar dan Batu Kalang Tarusan. Di samping itu kabupaten Pesisir Selatan juga memiliki objek wisata sejarah Rumah Gadang Mandeh Rubiah, Mesjid Tua, Benteng Portugis dan kesenian Rabab Pasisie. Kawasan Mandeh merupakan salah satu Destinasi Utama Pariwisata Kabupaten (DUPK) sesuai dengan Peraturan Daerah Nomor 2 tahun 2015 tentang Rencana Induk Pembangunan Kepariwisataan Kabupaten Pesisir Selatan. Masing-masing daerah objek wisata tersebut di atas memiliki berbagai kelemahan sehingga perlu adanya potensi investasi sebagai berikut : 1) penambahan boat dan sumberdaya manusia sebagai pemandu wisata, 2) pembangunan sarana dan prasarana penunjang kegiatan pariwisata, 3) pembangunan infrastruktur dan penambahan wahana atraksi serta infrastruktur permainan laut, 4) pembangunan hotel, resort, salon kecantikan dan SPA, tempat hiburan, biro perjalanan dan travel serta fasilitas lainnya seperti pembangunan pusat kuliner dan pembangunan area wisata pedesaan, pembangunan kolam renang air laut, 5) konservasi biodata endemik. Sehubungan dengan hal di atas pemerintah kabupaten Pesisir Selatan terus berinovasi mengembangkan sektor pariwisata sebagai upaya meningkatkan jumlah kunjungan wisatawan ke daerah tersebut. Menurut (BPS, 2019) setiap tahun terjadi peningkatan jumlah wisatawan yang berkunjung ke kabupaten Pesisir Selatan seperti tahun 2009 (13.650 orang), tahun 2010 (111.623 orang), tahun 2011 (116.558 orang), tahun 2012 (307.146 orang), tahun 2013 (587.634 orang), tahun 2014 (1.546.235 orang), tahun 2015 (2.001.600 orang), tahun 2016 (1.981.500 orang), tahun 2017 (2.351.700 orang) dan tahun 2018 (2.481.464 orang). Kabupaten Pesisir Selatan termasuk Kawasan Ekonomi Khusus (KEK) sebagai daerah tujuan wisata dengan berbagai jenis objek wisatanya seperti wisata alam 16 buah, wisata bahari 42 buah, wisata sejarah 11 buah dan wisata field trip 3 buah dengan totalnya 72 buah.

Provinsi Sumatera Barat terdiri dari 12 kabupaten dan 7 kota dengan berbagai objek wisata yang tersebar pada berbagai kabupaten dan kota dan ramai dikunjungi oleh wisatawan dari berbagai negara seperti Malaysia (3.564 orang), Thailand (55 orang) Australia (495 orang), Perancis (158 orang), Jerman (37 orang), India (21 orang), Inggris (41 orang), Cina (53 orang), Amerika Serikat (83 orang), Belanda (77 orang), Jepang (295 orang) dan lainnya 515 orang. (BPS, 2019). Berdasarkan uraian di atas ternyata sektor pariwisata sebagai sektor unggulan di kabupaten Pesisir Selatan dan provinsi Sumatera Barat masih banyak kekurangan dan kelemahan sehingga produk wisata sehingga produk wisata tersebut perlu dibenahi. Rumusan masalah penelitian adalah berapakah besar potensi lapangan usaha unggulan yang mendukung sektor pariwisata di kabupaten Pesisir Selatan dan provinsi Sumatera Barat? Tujuan penelitian ntuk 
mengetahui besar potensi lapangan usaha unggulan yang mendukung sektor pariwisata di kabupaten Pesisir Selatan dan provinsi Sumatera Barat.

\section{Landasan Teori \\ Produk Domestik Regional Bruto (PDRB)}

Pendapatan nasional dihitung menurut harga berlaku dan menurut harga tetap (Nanga, 2001). Pendapatan nasional pada harga berlaku yaitu nilai-nilai barang dan jasa-jasa yang dihasilkan suatu negara dalam suatu tahun dan dinilai menurut harga-harga berlaku pada tahun tersebut sehingga bila dibandingkan data pendapatan nasional dalam berbagai tahun nilainya akan berbeda-beda dan menunjukkan kecenderungan yang semakin meningkat dari tahun ke tahun. Pertambahan nilai tersebut disebabkan oleh faktor pertambahan fiskal barang dan jasa yang dihasilkan dalam perekonomian tersebut dan kenaikan harga-harga yang berlaku dari satu periode ke periode lainnya. Pertumbuhan perekonomian diukur dari pertumbuhan yang sebenarnya dalam barang dan jasa yang diproduksi. Untuk menghitung kenaikannya dari tahun ketahun, barang dan jasa yang dihasilkan harus dihitung pada harga tetap yaitu harga yang berlaku pada tahun tertentu yang seterusnya digunakan untuk menilai barang dan jasa yang dihasilkan pada tahuntahun lainnya. Nilai pendapatan nasional yang didapat dalam penghitungan secara ini disebut pendapatan nasional pada harga tetap atau pendapatan nasional riil. Konsep pendapatan nasional dapat dibedakan antara pengertian netto dan bruto. Pendapatan Nasional Bruto (PNB) perlu dikurangi oleh depresiasi untuk memperoleh Pendapatan Nasional Netto (PNN) Selanjutnya PNN dapat dibedakan menurut harga pasar dan harga faktor. PNN menurut harga faktor disebut dengan Pendapatan Negara $(\mathrm{PN})$ dimana PN $=$ PNB pajak tak langsung + subsidi - depresiasi akan tetapi dalam penghitungan di Indonesia subsidi tidak dihitung sehingga $\mathrm{PN}=\mathrm{PNB}-$ pajak tak langsung - depresiasi (Nanga, 2001).

\section{Pertumbuhan Ekonomi}

Sebuah negara disebut mengalami pertumbuhan ekonomi bila terjadi peningkatan Gross National Product (GNP) riil di negara tersebut sebagai indikator keberhasilan pembangunan ekonomi. Menurut (Yanuar, 2009) pertumbuhan ekonomi adalah proses kenaikan kapasitas produksi suatu perekonomian yang diwujudkan dalam bentuk kenaikan pendapatan nasional tapi tidak dikaitkan dengan pertumbuhan jumlah penduduk. Pertumbuhan ekonomi identik dengan kenaikan kapasitas produksi yang diwujudkan melalui kenaikan pendapatan nasional. Menurut (Sukirno, 2011) terdapat 6 karakteristik pertumbuhan ekonomi modern yang muncul dalam analisis berdasarkan produk nasional dan komponennya tenaga kerja, penduduk dan lainnya sebagai berikut : 1) terjadi laju pertumbuhan ekonomi dan produk per kapita yang cepat, 2) adanya peningkatan produktivitas masyarakat, 3) terjadi perubahan struktural yang tinggi, 4) adanya urbanisasi dalam negara, 5) melakukan ekspansi ke negara maju, 6) terjadinya arus barang, modal dan manusia antar bangsa di dunia. Selanjutnya (Yanuar, 2009) faktor-faktor ekonomi yang mempengaruhi bisnis sebagai berikut : 1) sumber daya manusia, 2) sumber daya alam, 3) kemajuan IPTEK, 4) tingkat inflasi, 5) tingkat suku bunga. Sumberdaya manusia akan menentukan keberhasilan pembangunan nasional melalui kuantitas dan kualitas penduduk. Jumlah penduduk yang banyak merupakan pasar potensial untuk memasarkan hasil-hasil produksi sementara kualitas penduduk menentukan seberapa besar produktivitas yang ada. Sumber daya modal dibutuhkan manusia untuk mengolah bahan mentah tersebut. Pembentukan modal dan investasi ditujukan untuk menggali dan mengolah kekayaan. Sumber daya modal berupa barangbarang modal sangat penting bagi perkembangan dan kelancaran pembangunan ekonomi karena barangbarang modal juga dapat meningkatkan produktivitas. Sumberdaya alam meliputi tanah dan kekayaan alam sangat mempengaruhi pertumbuhan industri suatu negara terutama dalam penyediaan bahan baku produksi. Keahlian dan kewirausahaan dibutuhkan untuk mengolah bahan mentah dari alam menjadi sesuatu yang bernilai lebih tinggi yang disebut juga sebagai proses produksi.

\section{Model Pertumbuhan Ekonomi}

\section{Teori dan Model Pertumbuhan Ekonomi Rostow}

Menurut Rostow pertumbuhan ekonomi suatu negara akan mengalami tahapan sebagai berikut : 1) masyarakat tradisional, 2) transisi (pratake off) terjadi peralihan struktur tenaga kerja dari pertanian ke industri, 3) tinggal landas (take off) adanya hambatan dalam struktur sosial, 4) menuju kedewasaan, 5) masa 
konsumsi tinggi (Jhingan, 2003). Rostow juga menciptakan frase less developed dimana sebuah negara masih mengandalkan sektor tradisional dan frase more developed dimana sebuah negara yang sudah mencapai tahap industrialisasi mengandalkan sektor kapitalis modern. Tahap yang berbeda ini bertujuan untuk mengidentifikasi variabel kritis atau strategis yang dianggap mengangkat kondisi yang cukup dan perlu untuk perubahan dan transisi menuju tahapan baru yang berkualitas. Teori Rostow secara mendasar bersifat unilinear dan universal serta dianggap bersifat permanen.

\section{Teori dan Model Pertumbuhan Ekonomi Harrod Domar}

Teori ini merupakan perkembangan dari teori Keynes karena Keynes tidak membahas masalah ekonomi jangka panjang. Harrod Domard mencoba menganalisis syarat-syarat agar ekonomi dapat tumbuh dan berkembang dalam jangka panjang (steady growth) dengan asumsi sebagai berikut : 1) perekonomian berada dalam kondisi full employment, 2) perekonomian hanya terdiri dari household dan firm, 3) besar private saving sama dengan national income, 4) Marginal Propensity to Save, Capital Output Ratio dan Incremental Capital Output Ratio dianggap konstan (Jhingan, 2003).

\section{Teori Model Pertumbuhan Ekonomi Solow}

Model pertumbuhan ekonomi Solow dibangun berdasarkan perekonomian kapitalis maju dan mengevaluasi persyaratan steady growth negara maju. Teori ini memberikan analisis statis bagaimana keterkaitan antara akumulasi modal, pertumbuhan populasi penduduk, perkembangan teknologi dan pengaruhnya terhadap tingkat produksi output dengan asumsi sebagai berikut : 1) tidak ada perubahan pada angkatan kerja dan teknologi ketika terjadi proses akumulasi modal dalam perekonomian, 2) pertumbuhan ekonomi berkelanjutan dapat terjadi, maka perlu pertumbuhan populasi dan kemajuan teknologi (Jhingan, 2003).

\section{METODE PENELITIAN}

Metode penelitian merupakan cara ilmiah untuk mendapatkan data yang valid dengan tujuan dapat ditemukan, dikembangkan dan dibuktikan pada pengetahuan tertentu sehingga dapat digunakan untuk memahami, memecahkan dan mengantisipasi masalah (Sugiyono, 2014). Jenis penelitian bersifat kuantitatif menggunakan data sekunder berupa angka bersumber dari Badan Pusat Statistik (BPS) kabupaten Pesisir Selatan dan provinsi Sumatera Barat berupa data PDRB Atas Dasar Harga Konstan (ADHK) tahun 2010 selama tahun 2014 - 2018. Teknik sampling yang digunakan non probability sampling dengan sampling jenuh (sensus) adalah teknik penentuan sampel bila semua anggota populasi digunakan sebagai sampel dan jumlah populasinya relatif sedikit (Sugiyono, 2014). Data penelitian kuantitatif dikumpulkan melalui studi pustaka berupa data time series dan cross section (data panel) sebagai unit-unit individu yang sama dan diamati dalam kurun waktu tertentu (Prasetyo dan Firdaus, 2009). Untuk menentukan sektor unggulan sebuah daerah digunakan indeks Location Quotient (LQ) menunjukkan besarnya peranan sektor perekonomian suatu wilayah dengan membandingkan sektor yang sama pada wilayah yang lebih besar (Sjafrizal, 2008). Metode ini digunakan untuk mengidentifikasi sektor ekonomi potensial yang menjadi unggulan dan dapat dikembangkan di suatu wilayah serta untuk mengidentifikasi comparative advantage suatu wilayah dengan rumus menurut (Sjafrizal, 2008) $\mathrm{LQ}=\left(\mathrm{V}_{\mathrm{ik}} / \mathrm{V}_{\mathrm{k}}\right) /\left(\mathrm{V}_{\mathrm{ip}} / \mathrm{V}_{\mathrm{p}}\right)$ dimana $\mathrm{V}_{\mathrm{ip}}=\mathrm{PDRB}$ sektor i daerah $\mathrm{k}$ (kabupaten/kota) dalam pembentukan PDRB, $\mathrm{V}_{\mathrm{k}}=$ PDRB total semua sektor di daerah $\mathrm{k}$, $\mathrm{V}_{\mathrm{ip}}=$ PDRB sektor i daerah referensi $\mathrm{p}$ (provinsi) dalam pembentukan PDRB daerah referensi $\mathrm{p}$ dan $\mathrm{V}_{\mathrm{p}}=$ PDRB total semua sektor di daerah referensi p. Berdasarkan hasil perhitungan LQ dapat diketahui konsentrasi kegiatan pada wilayah tertentu dengan kriteria sebagai berikut :

1. Jika $L Q=1$ berarti sektor i di wilayah analisis $\mathrm{k}$ bukan merupakan sektor unggulan (sektor yang tingkat spesialisasinya sama dengan wilayah referensi)

2. Jika LQ > 1 berarti sektor i di wilayah analisis k merupakan sektor unggulan (tingkat spesialisasinya lebih tinggi dari wilayah referensi).

3. Jika LQ $<1$ berarti sektor $\mathrm{i}$ di wilayah analisis $\mathrm{k}$ bukan merupakan sektor unggulan (tingkat spesialisasinya lebih rendah dari wilayah referensi). 
Penelitian ini kabupaten Pesisir Selatan sebagai wilayah analisis dan wilayah referensinya provinsi Sumatera Barat. Metode LQ memiliki kelebihan dalam hal penyelesaiannya mudah dilakukan akan tetapi juga memiliki keterbatasan terutama menyangkut wilayah penelitian yang tidak jelas (Hendayana, 2003).

\section{HASIL DAN PEMBAHASAN}

\section{Gambaran Umum Kabupaten Pesisir Selatan}

Kabupaten Pesisir Selatan sebuah kabupaten di Sumatera Barat dengan luas wilayah $5.749,89 \mathrm{~km}^{2}$ dan jumlah penduduk sekitar 420.000 orang. Kabupeten Pesisir Selatan terletak di bagian Selatan provinsi Sumatera Barat dengan ibu kotanya Painan berjarak sekitar $75 \mathrm{~km}$ dari kota Padang. Kabupaten Pesisir Selatan terdiri dari 15 kecamatan, 182 nagari dan 47 pulau kecil yang menyebar di sisi pantai kabupaten Pesisir Selatan serta dilewati oleh 22 aliran sungai. Desa pesisir / tepi laut adalah desa yang berbatasan langsung dengan sumber kehidupan rakyat sebagian besar tergantung pada potensi laut. Jenis usaha yang menunjang sektor pariwisata di kabupaten Pesisir Selatan terdapat penginapan 36 buah, agen perjalanan 9 buah dan toko souvenir tidak ada (BPS, 2019). Di sini juga tidak terdapat hotel berbintang sehingga para wisatawan asing atau domestik kurang nyaman untuk beristirahat setelah berwisata apalagi toko souvenir tempat menjual cendera mata tidak tersedia.

\section{Pertumbuhan Ekonomi Kabupaten Pesisir Selatan}

Nilai PDRB kabupaten Pesisir Selatan ADHB 2010 tahun 2018 mencapai Rp 13.642.649,16 juta. Secara nominal nilai PDRB ini mengalami kenaikan Rp 1.120.730,48 juta dibandingkan tahun 2017 mencapai Rp 12.521.918,68 juta. Naiknya nilai PDRB ini pengaruhi oleh kenaikan produksi di semua lapangan usaha dan adanya inflasi. Berdasarkan harga konstan tahun 2010 angka PDRB juga mengalami kenaikan dari Rp 8.679.053,24 juta pada ahun 2017 menjadi Rp 9.144.497,20 juta tahun 2018. Hal ini menunjukkan selama tahun 2018 kabupaten Pesisir Selatan mengalami pertumbuhan ekonomi sebesar $5,36 \%$ lebih lambat dibandingkan tahun sebelumnya. Penurunan laju pertumbuhan ekonomi ini murni karena melemahnya harga beberapa komoditi unggulan di kabupaten Pesisir Selatan.

Peranan berbagai lapangan usaha ekonomi dalam memproduksi barang dan jasa sangat menentukan struktur ekonomi suatu daerah. Struktur ekonomi yang terbentuk dari nilai tambah yang diciptakan oleh setiap lapangan usaha menggambarkan seberapa besar ketergantungan suatu daerah terhadap kemampuan berproduksi dari setiap lapangan usaha. Selama 5 tahun terakhir $(2014$ - 2018) struktur perekonomian kabupaten Pesisir Selatan masih didominasi oleh 5 kategori lapangan usaha diantaranya pertanian, kehutanan, dan perikanan, perdagangan besar dan eceran, reparasi mobil dan sepeda motor, konstruksi, industri pengolahan, administrasi pemerintahan, pertahanan dan jaminan sosial wajib. Hal ini dapat dilihat dari peranan masing-masing lapangan usaha terhadap pembentukan PDRB kabupaten Pesisir Selatan.

Peranan terbesar dalam pembentukan PDRB kabupaten Pessel tahun 2018 dihasilkan oleh lapangan usaha pertanian, kehutanan dan perikanan mencapai 39,48\% (angka ini menurun dari 41,67\% tahun 2014). Urutan kedua lapangan usaha lapangan usaha perdagangan besar dan eceran, reparasi mobil dan sepeda motor $12,62 \%$ (naik dari 10,93\% tahun 2014) kemudian disusul oleh lapangan usaha konstruksi $10,77 \%$ (naik dari 9,38\% tahun 2014). Berikutnya lapangan usaha industri pengolahan 7,40\% (turun dari $8,17 \%$ tahun 2014) dan lapangan usaha administrasi pemerintahan, pertahanan dan jaminan sosial wajib 6,04\% (turun dari 6,35\% tahun 2014). Diantara kelima lapangan usaha tersebut, perdagangan besar dan eceran, reparasi mobil serta konstruksi merupakan kategori yang terus meningkat peranannya. Sebaliknya pertanian, kehutanan dan perikanan serta industri pengolahan peranannya berangsur-angsur turun. Sedangkan lapangan usaha administrasi pemerintahan, pertahanan dan jaminan sosial wajib peranannya berfluktuasi namun cenderung meningkat. Sementara itu peranan lapangan usaha lainnya masing-masing kurang dari 6,04\%. Salah satu penyebab turunnya peranan pertanian, kehutanan dan perikanan karena kurang luasnya lahan dan faktor harga komoditi pada lapangan usaha tersebut. Lambatnya kenaikan harga produk lapangan usaha tersebut dibandingkan produk lain juga menjadi penyebab turunnya peranan lapanagan usaha pertanian, kehutanan dan perikanan.

Pertumbuhan ekonomi tahun 2018 dipengaruhi adanya investasi dan perbaikan kinerja yang berkaitan dengan pariwisata. Investasi tersebut berupa pembangunan proyek infrastruktur seperti perbaikan dan pembenahan terutama tempat-tempat kawasan objek wisata di kabupaten Pesisir Selatan. Hal ini sejalan 
dengan tekad pemerintah kabupaten Pesisir Selatan yang telah mencanangkan bahwa daerah Pesisir Selatan salah satu destinasi wisata di Indonesia dan Sumatera Barat khususnya. Dari 17 lapangan usaha ekonomi yang ada semuanya mengalami laju pertumbuhan positif seperti Tabel 1 berikut.

Tabel 1

Laju Pertumbuhan PDRB Kabupaten Pesisir Selatan ADHK 2010 Menurut Lapangan Usaha (dalam Milyar Rupiah)

\begin{tabular}{|c|c|c|c|c|c|c|}
\hline No. & Lapangan Usaha & 2014 & 2015 & 2016 & $2017^{*}$ & $2018 * *$ \\
\hline 1. & $\begin{array}{l}\text { Pertanian, kehutanan dan } \\
\text { perikanan }\end{array}$ & 2952748,20 & 3116574,26 & 3185518,28 & 3286249,91 & 3399052,01 \\
\hline 2. & Pertambangan dan penggalian & 283480,60 & 296634,08 & 313606,68 & 322921,69 & 336620,10 \\
\hline 3. & Industri pengolahan & 652490,92 & 681307,33 & 726922,47 & 740234,30 & 763429,46 \\
\hline 4. & Pengadaan listrik dan gas & 2437,18 & 2541,86 & 2799,18 & 2950,74 & 3113,32 \\
\hline 5. & $\begin{array}{l}\text { Pengadaan air, pengelolaan } \\
\text { sampah, limbah dan daur ulang }\end{array}$ & 5379 & 5603,92 & 5953,65 & 6205,73 & 6365,91 \\
\hline 6. & Konstruksi & 701764,15 & 744812,28 & 802541,38 & 878642,87 & 946934,90 \\
\hline 7. & $\begin{array}{l}\text { Pedagangan besar dan eceran; } \\
\text { reparasi mobil dan sepeda motor }\end{array}$ & 888870,62 & 941562,63 & 1006268,42 & 1088007,23 & 1166122,34 \\
\hline 8. & $\begin{array}{l}\text { Transportasi } \\
\text { dan pergudangan }\end{array}$ & 272286,63 & 294012,90 & 319568,07 & 347284,58 & 375574,51 \\
\hline 9. & $\begin{array}{l}\text { Penyediaan akomodasi dan makan } \\
\text { minum }\end{array}$ & 70823,89 & 75857,71 & 84164,00 & 93233,07 & 100790,35 \\
\hline 10. & $\begin{array}{l}\text { Informasi } \\
\text { dan komunikasi }\end{array}$ & 475114,70 & 515866,60 & 565213,72 & 627992,59 & 685900,50 \\
\hline 11. & Jasa keuangan dan asuransi & 167161,73 & 173522,26 & 185015,85 & 188723,74 & 189666,02 \\
\hline 12. & Real estate & 104642,28 & 110703,39 & 117146,74 & 123254,97 & 128884,75 \\
\hline 13. & Jasa perusahaan & 4013,55 & 4230,45 & 4446,97 & 4679.40 & 4939,73 \\
\hline 14. & $\begin{array}{l}\text { Administrasi pemerintahan, } \\
\text { pertahanan dan } \\
\text { jasa sosial wajib }\end{array}$ & 447415,88 & 462302,57 & 486309,52 & 511309,66 & 547509,17 \\
\hline 15. & Jasa pendidikan & 199842,26 & 216159,02 & 235976,92 & 252425,19 & 268259,23 \\
\hline 16. & $\begin{array}{l}\text { Jasa kesehatan } \\
\text { dan kegiatan sosial }\end{array}$ & 92456,62 & 99175,46 & 104660,31 & 112926,32 & 121454,51 \\
\hline \multirow[t]{2}{*}{17.} & Jasa lainnya & 71608,24 & 75347,33 & 104660,31 & 91811,27 & 99880,38 \\
\hline & PDRB & 7392536,44 & 7816214,05 & 8232592,61 & 8679053,24 & 9144497,20 \\
\hline
\end{tabular}

Sumber : BPS, 2019

Keterangan : * dan ** (angka sementara)

\section{Gambaran Umum Provinsi Sumatera Barat}

Propinsi Sumatera Barat memiliki luas sekitar 42,2 ribu $\mathrm{km}^{2}$ setara dengan 2,27\% dari luas negara Republik Indonesia terdiri dari 12 kabupaten dan 9 kota diantaranya kepulauan Mentawai memiliki luas terluas 6,01 ribu $\mathrm{km}^{2}$ dan kota Padang Panjang memiliki luas terkecil $23 \mathrm{~km}^{2}$. Kondisi alam propinsi Sumatera Barat sampai saat ini memiliki luas kawasan hutan lindung sekitar 44,5\% dari luas keseluruhan dan memiliki banyak sekali potensi alam yang bisa digali dan diberdayakan (BPS, 2019).

\section{Pertumbuhan Ekonomi Provinsi Sumatera barat}

Perekonomian Sumatera Barat tahun 2018 diukur berdasarkan PDRB ADHK2010 mencapai Rp 230,53 triliun dan PDRB per kapita mencapai Rp 42,57 juta triliun. Ekonomi Sumatera Barat tahun 2018 tumbuh 5,14\% melambat 5,29\% dibandingkan tahun 2017. Dari sisi produksi kinerja lapangan usaha pertanian merupakan kontribusi terbesar dalam perekonomian Sumatera Barat mengalami pertumbuhan dari 3,40\% tahun 2017 menjadi 3,46\% tahun 2018. Kenaikan dari sisi pengeluaran disebabkan karena membaiknya kinerja pengeluaran konsumsi pemerintah dari -0,5\% tahun 2017 menjadi 4,63\% tahun 2018 . Dari sisi produksi lapngan usaha konstruksi mengalami pertumbuhan tertinggi diantara lapangan usaha lainnya sebesar $7,40 \%$. Dari sisi pengeluaran disebabkan oleh penurunan pada hampir semua komponen pengeluaran kecuali pengeluaran konsumsi pemerintah meningkat 36,34\%.. Bidang transportasi dan pergudangan tumbuh melambat. Turunnya jumlah penumpang angkutan udara akibat naiknya tarif tiket pesawat dan kargo berbayar juga ikut mempengaruhi. Dari sisi pengeluaran ekspor terkontraksi pada 
komoditas lemak, minyak hewan dan karet 20,93\% dibandingkan periode yang sama tahun sebelumnya. Begitu juga impor turun 3,06\%. Struktur perekonomian Sumatera Barat menurut lapangan usaha masih didominasi sektor pertanian, kehutanan dan perikanan 22,67\%. Sedangkan perdagangan eceran dan reparasi mobil, sepeda motor kontribusi $15,27 \%$ dan transportasi serta pergudangan $12,59 \%$. Untuk lebih jelasnya dapat dilihat seperti Tabel 2 berikut.

Tabel 2

Laju Pertumbuhan PDRB Provinsi Sumatera Barat ADHK 2010 Menurut Lapangan Usaha (Milyar Rupiah)

\begin{tabular}{|c|c|c|c|c|c|c|}
\hline No. & Lapangan Usaha & 2014 & 2015 & 2016 & $2017^{*}$ & $2018 * *$ \\
\hline 1. & $\begin{array}{l}\text { Pertanian, } \\
\text { kehutanan dan } \\
\text { perikanan }\end{array}$ & 32151489,71 & 33546757,19 & 34222561,72 & 35387634,92 & 36612272,53 \\
\hline 2. & $\begin{array}{l}\text { Pertambangan } \\
\text { dan penggalian }\end{array}$ & 8049 & 8682 & 8886 & 9133 & 6705049,43 \\
\hline 3. & $\begin{array}{l}\text { Industri } \\
\text { pengolahan }\end{array}$ & 17424 & 18322 & 19792 & 20835 & 16445055,91 \\
\hline 4. & $\begin{array}{l}\text { Pengadaan listrik } \\
\text { dan gas }\end{array}$ & 140011,69 & 145686,13 & 161628,93 & 168196,58 & 175080,06 \\
\hline 5. & $\begin{array}{l}\text { Pengadaan air, } \\
\text { pengelolaan } \\
\text { sampah, limbah } \\
\text { dan daur ulang }\end{array}$ & 133696,91 & 141707,83 & 150771,11 & 156736,19 & 160240,92 \\
\hline 6. & Konstruksi & 11523579,91 & 12315040,24 & 13126836,91 & 14075895,58 & 15066989,63 \\
\hline 7. & $\begin{array}{l}\text { Pedagangan } \\
\text { besar dan eceran; } \\
\text { reparasi mobil } \\
\text { dan sepeda } \\
\text { motor }\end{array}$ & 20523147,03 & 21626609,65 & 22796932,47 & 24279260,45 & 25985871,63 \\
\hline 8. & $\begin{array}{l}\text { Transportasi dan } \\
\text { pergudangan }\end{array}$ & 14929948,87 & 16259293,39 & 17506914,87 & 18762202,18 & 19975310,85 \\
\hline 9. & $\begin{array}{l}\text { Penyediaan } \\
\text { akomodasi dan } \\
\text { makan minum }\end{array}$ & 1329396,18 & 1420410,28 & 1557102,43 & 1693494,32 & 1832878,56 \\
\hline 10. & $\begin{array}{l}\text { Informasi dan } \\
\text { komunikasi }\end{array}$ & 8322873,30 & 9080556,08 & 9934334,82 & 10802637,25 & 11728422,78 \\
\hline 11. & $\begin{array}{l}\text { Jasa keuangan } \\
\text { dan asuransi }\end{array}$ & 4041345,16 & 4188231,47 & 4524388,29 & 4619805,20 & 4665415,80 \\
\hline 12. & Real estate & 2609894,33 & 2748095,83 & 2895556,33 & 3025615,61 & 3166853,19 \\
\hline 13. & Jasa perusahaan & 585985,89 & 620607,06 & 651284,00 & 685063,40 & 722425,15 \\
\hline 14. & $\begin{array}{l}\text { Administrasi } \\
\text { pemerintahan, } \\
\text { pertahanan dan } \\
\text { jasa sosial wajib }\end{array}$ & 7511115,63 & 7895347,42 & 8286949,05 & 8659075,43 & 9175850,47 \\
\hline 15. & Jasa pendidikan & 4657618,64 & 5022030,69 & 5416448,83 & 5954627,35 & 6382703,06 \\
\hline 16. & $\begin{array}{l}\text { Jasa kesehatan } \\
\text { dan kegiatan } \\
\text { sosial }\end{array}$ & 1749926,04 & 1881299,00 & 1984293,52 & 2154588,55 & 2311450,41 \\
\hline 17. & $\begin{array}{l}\text { Jasa lainnya } \\
\text { PDRB }\end{array}$ & $\begin{array}{r}2067170,04 \\
133340836,44 \\
\end{array}$ & $\begin{array}{r}2264684,32 \\
140719474,19 \\
\end{array}$ & $\begin{array}{r}2476536,98 \\
148134243,89 \\
\end{array}$ & $\begin{array}{r}2673386,50 \\
155976491,52 \\
\end{array}$ & $\begin{array}{r}2883397,98 \\
163995268,35 \\
\end{array}$ \\
\hline
\end{tabular}

Sumber : BPS, 2019.

Keterangan : * dan ** (angka sementara)

Pertumbuhan investasi mayoritas hanya berasal dari realisasi anggaran belanja pemerintah. Minimnya investasi swasta tercermin dari penyaluran kredit yang hanya tumbuh 1,5\% bahkan untuk kredit investasi justeru terkontraksi hingga 15,5\%. Investasi swasta harus ditingkatkan lagi untuk memaksimalkan pertumbuhan ekonomi termasuk sektor lainnya seperti pariwisata dimana sektor pariwisata menjadi prioritas pertumbuhan ekonomi Sumatera Barat dimasa yang akan datang dengan adanya kebijakan pusat dan daerah yang sinkron untuk mendukung pengembangan sektor pariwisata. Untuk investasi pemerintah setempat 
membuka peluang yang luas bagi perusahaan asing maupun dalam negeri untuk berinvestasi dengan prioritas di bidang pariwisata, energi terbarukan, infrastruktur, industri pengolahan, pertanian dan perikanan.

\section{Sektor Unggulan}

Penentuan komoditas unggulan suatu daerah merupakan langkah awal menuju pembangunan yang berpihak pada konsep efisiensi untuk meraih keunggulan komparatif dan kompetitif dalam menghadapi globalisasi perdagangan. Langkah menuju efisiensi dapat ditempuh dengan menggunakan komoditas yang mempunyai keunggulan komparatif ditinjau dari supply dan demand. Dari sisi supply, komoditas unggulan dicirikan oleh superioritas dalam pertumbuhan pada kondisi biofisik, teknologi dan kondisi sosial ekonomi yang dapat dijadikan andalan untuk meningkatkan pendapatan. Dari sisi demand, komoditas unggulan dicirikan oleh kuatnya permintaan di pasar domestik dan internasional. Sektor unggulan mampu memberikan kontribusi besar terhadap PDRB maupun terhadap produksi nasional atau merupakan sektor yang mampu menyerap tenaga kerja lebih banyak dibandingkan dengan sektor yang sama ditingkat regional atau nasional. Pengertian unggulan atau basis meliputi sektor-sektor aktivitas dalam perekonomian suatu daerah dan mampu mempunyai daya dorong terhadap berkembangnya kegiatan ekonomi lainnya serta mendatangkan mutiplier effect bagi suatu daerah dari sumber-sumber yang berada di luar daerah tersebut (Sjafrizal, 2008).

Berdasarkan analisis LQ kabupaten Pesisir Selatan mempunyai 4 lapangan usaha unggulan (pertanian, konstruksi, informasi dan komunikasi, administrasi pemerintahan dan pertahanan, jaminan sosial). Dari 4 lapangan usaha unggulan hanya lapangan usaha pertanian yang dominan mendukung pariwisata di Pesisir Selatan. Investor dapat berinvestasi pada lapangan usaha pertanian yang mendukung pariwisata Kabupaten Pesisir Selatan tapi tidak menutup kemungkinan pada 3 lapangan usaha lainnya . Lapangan usaha unggulan lainnya seperti konstruksi (1,06), informasi dan komunikasi (1,11), administrasi pemerintahan dan pertahanan, jaminan sosial $(1,05)$. Untuk menggenjot hasil pertanian khususnya tanaman pangan pemerintah setempat menerapkan teknologi padi salibu, peningkatan jumlah alat mesin pertanian dan teknologi pertanian lainnya untuk mendukung program ketahanan pangan nasional di bidang pertanian sehingga hasil panen maksimum dan berkualitas serta menekan biaya yang harus dikeluarkan petani dalam mengelola lahan hingga panen. Selain padi kabupaten Pesisir Selatan menjadikan jagung hibrida sebagai komoditi unggulan karena selain memiliki nilai ekonomi yang tinggi, potensi pengembangannya bisa dilakukan di semua kecamatan yang ada. Jagung merupakan salah satu komoditi utama tanaman pangan yang mempunyai peran strategis dalam pembangunan pertanian dan perekonomian bangsa karena memiliki produk unggulan setelah padi. Pengembangannya dilakukan dengan memprioritaskan kecamatan yang dijadikan sentra melalui sistem tanam silang dari padi ke tanaman jagung dan lainnya. Kecamatan Silaut kabupaten Pesisir Selatan merupakan sentra pengembangan buah-buahan seperti salak, lengkeng, mangga, durian dan beberapa jenis lainnya. Hal ini dilakukan untuk mengalihkan sumber pendapatan keluarga nantinya terutama bila tanaman kelapa sawit tidak lagi produktif. Kecamatan Silaut menempati posisi sebagai kecamatan dengan ekonomi termaju di kabupaten Pesisir Selatan karena pertumbuhan ekonomi dominan pada sektor perkebunan.

Lapangan usaha unggulan provinsi Sumatera Barat adalah pertanian $(1,83)$, pengadaan air, pengelolaan sampah, limbah dan daur ulang $(1,22)$ perdagangan besar dan eceran, reparasi mobil dan sepeda motor $(1,11)$, transportasi dan perdagangan $(2,54)$, informasi dan komunikasi $(1,42)$, jasa kesehatan dan kegiatan sosial $(1,24)$ serta jasa lainnya $(1,05)$. Lapangan usaha yang mendukung sektor pariwisata provinsi Sumatera Barat yaitu lapangan usaha transportasi dan pergudangan karena membaiknya kinerja lapangan usaha ini tercermin dari meningkatnya permintaan kredit transportasi. Hal ini terjadi juga karena libur Lebaran dan tradisi mudik sehingga jumlah penumpang meningkat. Lapangan usaha pertanian dengan 10 komoditas pertanian layak dikembangkan untuk pasar ekspor seperti pinang, kopi, coklat, gambir, pala, kayu manis, cengkeh, vanilla, lada dan manggis. Dengan demikian komoditas ekspor Sumatera Barat tidak hanya sebatas produk Crude Palm Oil (CPO) atau sawit dan karet beserta turunannya yang selama ini mendominasi ekspor daerah. Pemerintah Daerah memberi pembinaan dan bantuan bibit kepada petani agar jumlah petani yang mengembangkan komoditas tersebut semakin banyak sehingga petani tidak tergantung lagi pada sawit dan karet. Untuk lebih jelasnya hasil perhitungan analisis LQ kabupaten Pesisir Selatan dan provinsi Sumatera Barat pada masing-masing lapangan usaha seperti berikut. 
Tabel 3.

Hasil Perhitungan Indeks LQ dan Potensi Ekonomi Kabupaten Pesisir Selatan dan Provinsi Sumatera Barat

\begin{tabular}{|c|c|c|c|c|}
\hline Lapangan Usaha & $\begin{array}{c}\text { Rata- Rata Indeks LQ } \\
\text { Kabupaten Pesisir } \\
\text { Selatan }\end{array}$ & $\begin{array}{c}\text { Potensi Ekonomi } \\
\text { Kabupaten Pesisir } \\
\text { Selatan }\end{array}$ & $\begin{array}{c}\text { Rata-Rata } \\
\text { Indeks LQ } \\
\text { Provinsi Sumatera Barat }\end{array}$ & $\begin{array}{c}\text { Potensi Ekonomi } \\
\text { Provinsi Sumatera } \\
\text { Barat }\end{array}$ \\
\hline Pertanian & 1,70 & Berpotensi & 1,83 & Berpotensi \\
\hline $\begin{array}{l}\text { Pertambangan dan } \\
\text { penggalian }\end{array}$ & 0,84 & Tidak berpotensi & 0,55 & Tidak berpotensi \\
\hline Industri pengolahan & 0,78 & Tidak berpotensi & 0,50 & Tidak berpotensi \\
\hline $\begin{array}{l}\text { Pengadaan listrik dan } \\
\text { gas }\end{array}$ & 0,47 & Tidak berpotensi & 0,08 & Tidak berpotensi \\
\hline $\begin{array}{l}\text { Pengadaan air, } \\
\text { pengelolaan sampah, } \\
\text { limbah dan daur } \\
\text { ulang }\end{array}$ & 0,73 & Tidak berpotensi & 1,22 & Berpotensi \\
\hline Konstruksi & 1,06 & Berpotensi & 0,91 & Tidak berpotensi \\
\hline $\begin{array}{l}\text { 7Perdagangan besar } \\
\text { dan eceran ; reparasi } \\
\text { mobil dan sepeda } \\
\text { motor }\end{array}$ & 0,77 & Tidak berpotensi & 1,11 & Berpotensi \\
\hline $\begin{array}{l}\text { Transportasi dan } \\
\text { pergudangan }\end{array}$ & 0,30 & Tidak berpotensi & 2,54 & Berpotensi \\
\hline $\begin{array}{l}\text { Penyediaan } \\
\text { akomodasi dan } \\
\text { makan minum }\end{array}$ & 0,90 & Berpotensi & 0,41 & Tidak berpotensi \\
\hline $\begin{array}{l}\text { Informasi dan } \\
\text { komunikasi }\end{array}$ & 1,11 & Berpotensi & 1,42 & Berpotensi \\
\hline $\begin{array}{l}\text { Jasa keuangan dan } \\
\text { asuransi }\end{array}$ & 0,73 & Tidak berpotensi & 0,78 & Tidak berpotensi \\
\hline Real estate & 0,69 & Tidak berpotensi & 0,70 & Tidak berpotensi \\
\hline Jasa perusahaan & 0,12 & Tidak berpotensi & 0,26 & Tidak berpotensi \\
\hline $\begin{array}{l}\text { Administrasi } \\
\text { pemerintahan, } \\
\text { pertahanan dan } \\
\text { jaminan sosial }\end{array}$ & 1,05 & Berpotensi & 1,54 & Berpotensi \\
\hline Jasa pendidikan & 0,78 & Tidak berpotensi & 1,15 & Berpotensi \\
\hline $\begin{array}{l}\text { Jasa kesehatan dan } \\
\text { kegiatan sosial }\end{array}$ & 0,96 & Tidak berpotensi & 1,24 & Berpotensi \\
\hline Jasa lainnya & 0,63 & Tidak berpotensi & 1,05 & Berpotensi \\
\hline
\end{tabular}

Sumber : Data Diolah, 2019

\section{SIMPULAN}

Berdasarkan analisis LQ kabupaten Pesisir Selatan mempunyai 4 lapangan usaha unggulan yaitu 1) pertanian, 2) konstruksi, 3) informasi dan komunikasi, 4) administrasi pemerintah dan pertahanan, jaminan sosial tapi yang mendukung sektor pariwisata hanya lapangan usaha pertanian. Begitu juga provinsi Sumatera Barat mempunyai 7 lapangan usaha unggulan yaitu 1) pertanian, 2) pengadaan air, pengelolaan sampah, limbah dan daur ulang, 3) perdagangan besar dan eceran, reparasi mobil dan sepeda motor, 4) transportasi dan pergudangan, 5) informasi dan komunikasi, 6) jasa kesehatan dan kegiatan sosial, 7) jasa lainnya. Tapi yang mendukung sektor pariwisata dominan lapangan usaha transportasi dan pergudangan. Untuk jangka panjang lapangan usaha lainnya yang tidak jadi menjadi lapangan usaha unggulan yang mendukung sektor pariwisata provinsi Sumatera Barat dapat dijadikan sektor unggulan dengan memperbaiki sarana dan prasarana, memperhatikan lokasi, membuat berbagai macam kebijakan lainnya. Lapangan usaha unggulan yang mendukung sektor pariwisata di provinsi Sumatera Barat sangat cocok karena jumlah arus urbanisasi yang cukup tinggi dari kota dan kabupaten lainnya yang ada di provinsi Sumatera Barat serta provinsi lainnya di Indonesia. Dengan adanya lapagan usaha unggulan maka pemeritah dapat menarik para investor untuk berinvestasi dengan memberikan berbagai kemudahan dalam perizinan dan bunga bank sehingga jumlah pengangguran dapat teratasi. Pemerintah kabupaten Pesisir Selatan dan provinsi Sumatera Barat fokus pada pengembangan pariwisata karena banyaknya potensi wisata daerah setempat yang bisa dikemas untuk kebutuhan wisata dengan memanfaatkan kearifan lokal sebagai basis pengembangan daerah 
yang berdampak ekonomi bagi masyarakat sekitar. Adanya pengembangan wilayah yang didukung oleh infrastruktur yang ada memungkinkan perekonomian kabupaten Pesisir Selatan dan provinsi Sumatera Barat akan tumbuh dengan baik berbasis industri yang berpengaruh terhadap ketersediaan lapangan usaha industri yang ada dan mobilisasi tenaga kerja.

\section{DAFTAR PUSTAKA}

Adam, Latif. 2018. Perlu Pembangunan Infrastruktur Pariwisata Untuk Peningkatan Nilai Tambah. Jakarta : Lembaga Ilmu Pengetahuan Indonesia.

Arianti, Desi. 2016. Pengaruh Sektor Pariwisata Terhadap Perekonomian dan Keruangan Kota Bukittinggi (Pendekatan Analisis Input Output). Jurnal Pembangunan Wilayah dan Kota. 12(4). Desember $2016: 347-360$.

Badan Pusat Statistik. 2018. Kabupaten Pesisir Selatan Dalam Angka 2019. Painan.

Badan Pusat Statistik. 2018. Provinsi Sumatera Barat Dalam Angka 2019. Padang.

Hendayana, Rachmat. 2003. Aplikasi Metode Location Quotient (LQ) Dalam Penentuan Komoditas Unggulan Nasional. Jurnal Informatika Pertanian. $12: 1-21$.

Islami, Nurul. 2019. Analisis Sektor Potensial, Dapatkah Pariwisata Menjadi Lokomotif Baru Ekonomi Nusa Tenggara Barat? Journal of Indonesian Tourism, Hospitally and Recreation. 2(1). April $2019: 1$ -10 .

Jingan, M.L. 2003. Ekonomi Pembangunan dan Perencanaan. Jakarta : PT Raja Grafind Persada

Lenggogeni, Sari dan Elfindri. 2017.Creatourism:Mendukung Pembangunan Kepariwisataan Berkelanjutan. Padang: PT Mujur Jaya.

Mahmudi. 2010. Manajemen Keuangan Daerah. Jakarta : Penerbit Erlangga.

Nanga, Muana. 2001. Makroekonomi : Teori Masalah dan Kebijakan. Jakarta : PT Raja Grafindo Persada.

Sjafrizal. 2008. Ekonomi Regional. Teori dan Aplikasi. Padang : Baduose Media.

Sugiyono. 2014. Metode Penelitian Kuantitatif, Kualitatif dan $R \& D$. Bandung : Alfabeta.

Sukirno, Sadono. 2011. Ekonomi Pembangunan. Proses, Masalah dan Dasar Kebijakan. Jakarta : Kencana.

Syukriah, Erry. 2014. Pariwisata Sebagai Sektor Unggulan Kota Bandung. Jurnal Manajemen Resort\& Leisure. 11(1).

Yanuar. 2009. Ekonomi Makro : Suatu Analisis Untuk Konteks Indonesia. Jakarta : Yayasan Mpu Ajar Artha.

Yoeti, Oka A. 2008. Perencanaan dan Pengembangan Pariwisata. Jakarta : Pradnya Paramitha. 